\title{
PENGARUH TOTAL ASSET TURN OVER, RETURN ON ASSET DAN RETURN ON EQUITY TERHADAP ACCUMULATION DISTRIBUTION LINE
}

\author{
Luna Haningsih, Zulkifli, Caturida Meiwanto Doktoralina \\ Fakultas Ekonomi dan Bisnis Universitas Mercu Buana Jakarta \\ Email: lenina.umb@gmail.com qifli_ifi@yahoo.co.id chess302@gmail.com
}

\begin{abstract}
Fundamental and technical analysis is used by analysis to predict the trend of stock price and trading volume. Studies conducted aimed to determine the effect of fundamental analysis to technical analysis. Combining two forms of analysis can produce a more accurate prediction of the stock price movement of listed cement companies in Indonesia Stock Exchange. Research experts indicate that the fundamental and technical analysis can be used independently with the ability to predict stock price movements. This study combines both analysis in a model that can provide a more robust predictive capability in the Company's share price movements of cement. Fundamental analysis is the economy wide scope, one of the predictions of financial performance. In this study the total asset turnover, return on assets and return on equity to determine which stocks are pretty good. While technical analysis is used accumulation distribution line that has a better ability to predict future stock prices because the data contained technical stock price and trading volume to determine when to buy and sell momentum. These results indicate that the total asset turnover, return on assets and return on equity significantly influence the accumulation distribution line. While the individual that the return on equity has no significant effect. The results of this study are expected to improve knowledge for the readers, especially investors in order to obtain optimal benefits.
\end{abstract}

Keywords: Total Asset Turn Over, Return on Asset, Return on Equity and Accumulation Distribution Line

Abstrak: Analisis fundamental dan teknikal digunakan oleh para analis untuk memperkirakan tren harga dan volume perdagangan saham. Studi yang dilakukan bertujuan untuk mengetahui pengaruh analisis fundamental terhadap analisa teknikal. Apakah dengan menggabungkan kedua bentuk analisis ini dapat menghasilkan sebuah prediksi yang lebih tepat terhadap pergerakan harga saham Perusahaan semen yang terdaftar di Bursa Efek Indonesia. Hasil riset para ahli menunjukkan bahwa analisis fundamental maupun teknikal dapat digunakan secara terpisah yang memiliki kemampuan untuk memperkirakan pergerakan harga saham. Penelitian ini menggabungkan kedua analisis dalam sebuah model sehingga dapat memberikan kemampuan prediksi yang lebih kuat pada pergerakan harga saham Perusahaan semen. Analisa fundamental adalah ruang lingkup ekonomi secara luas, salah satunya prediksi kinerja keuangan. Dalam penelitian ini digunakan total asset turn over, return on asset dan return on equity untuk menentukan saham mana yang cukup baik. Sedangkan Analisis teknikal yang digunakan accumulation distribution line yang memiliki kemampuan lebih baik dalam memperkirakan harga saham kedepannya karena data teknikal terdapat harga dan volume perdagangan saham untuk menentukan momentum kapan membeli dan menjual. Hasil penelitian ini menunjukan bahwa total asset turn 
over, return on asset dan return on equity berpengaruh signifikan terhadap accumulation distribution line. Sedangkan secara individu bahwa return on equity tidak berpengaruh signifikan. Hasil studi ini diharapkan dapat meningkatkan pengetahuan bagi para pembaca khususnya investor agar memperoleh keuntungan yang optimal.

Kata kunci: Total Asset Turn Over, Return on Asset, Return on Equity dan Akumulasi Jalur Distribusi

\section{PENDAHULUAN}

Pasar modal merupakan alternatif investasi pada instrument keuangan jangka panjang penghimpun dana selain sistem perbankan. Dalam menjalankan fungsi ekonominya pasar modal menyediakan fasilitas untuk memindahkan dana dari pihak yang mempunyai kelebihan dana (lenders) kepada pihak yang memerlukan dana (borrowers). Dengan menginvestasikan kelebihan dana yang dimilikinya, lenders mengharapkan akan memperoleh imbalan dari penyerahan dana tersebut, dan borrowers tersedianya dana dari pihak luar memungkinkan melakukan investasi tanpa harus tersedianya dana dari hasil operasi perusahaan dengan harapan terjadi peningkatan produksi.

Keberadaan pasar modal ini akan memungkinkan para pemodal untuk melakukan diversifikasi investasi membentuk portofolio yaitu pengalokasian dana yang merupakan gabungan dari berbagai investasi sesuai risiko yang di tanggung dan tingkat keuntungan yang diharapkan. Oleh karena itu pemodal mempunyai berbagai pilihan investasi yang sesuai dengan preferensi risiko mereka, karena Pasar modal yang efisien memiliki hubungan yang positif antara risiko dan keuntungan yang diharapkan akan terjadi. Disamping itu investasi pada sekuritas juga mempunyai daya tarik lain yaitu likuiditasnya sehingga pemodal dapat melakukan investasi kapanpun dan memilih industri apapun yang mereka pilih sesuai analisis yang mereka lakukan dalam meminimalkan risiko dan memperoleh tingkat keuntungan yang diharapkan.

Mariana dan Wahidahwati (2008) meneliti Pengaruh Faktor-Faktor Fundamental dan Teknikal terhadap Harga Saham dengan hasil penelitian bahwa secara simultan Price Earning Ratio, Return on Asset, Debt Ratio, Current Ratio, Earning Per Share, Tingkat Suku Bunga, Inflasi, Nilai Transaksi Saham dan Volume Perdagangan Saham berpengaruh signifikan terhadap perubahan harga saham.

Pasaribu (2008) meneliti Pengaruh Variabel Fundamental terhadap Harga Saham Perusahaan Go Public di Bursa Efek Indonesia dengan hasil penelitian bahwa secara simultan pertumbuhan, profitabilitas, posisi leverage, likuiditas, dan efisiensi perusahaan berpengaruh signifikan terhadap harga saham.

Susilowati dan Turyanto (2011) meneliti Reaksi Signal Rasio Profitabilitas dan Rasio Solvabilitas terhadap Return Saham Perusahaan dengan hasil penelitian bahwa Earning Per Share, Net Profit Margin, Return on Asset, Return on Equity dan Debt to Equity Ratio secara simultan mempunyai pengaruh yang signifikan terhadap return saham.

Pandansari (2012) meneliti Analisis Faktor Fundamental terhadap Harga Saham dengan hasil penelitian bahwa Return on Asset, Debt to Equity Ratio dan Book Value Share secara simultan berpengaruh signifikan terhadap harga saham.

Bangun dan Setiawan (2012) meneliti Analisis Pengaruh Earning, Cash Flow, Nilai Buku dan Nilai Pasar terhadap Pergerakan Stock Return Pada Saham Lq 45 di Bursa Efek Indonesia dengan hasil penelitian bahwa secara simultan bahwa Earning, perubahan 
Earning, Earning tahun lalu, Cash flow from operation, perubahan Cash flow from operation, Cash flow from operation tahun lalu, Nilai buku, Nilai buku tahun lalu berpengaruh terhadap Stock Return.

Farkhan dan Ika (2012) meneliti Pengaruh Rasio Keuangan terhadap Return Saham Perusahaan Manufaktur di Bursa Efek Indonesia (Studi kasus Pada Perusahaan Manufaktur Sektor Food And Beverage) dengan hasil penelitian bahwa secara simultan Price Earning Ratio, Total Asset Turn Over, Current Ratio, Debt to Equity Ratio dan Return on Asset berpengaruh signifikan terhadap Return Saham.

Thohiri dan Sirahar (2013) meneliti Pengaruh Informasi Arus Kas dan Laba Bersih terhadap Volume Perdagangan Saham Pada Perusahaan Manufaktur yang terdaftar di Bursa Efek Indonesia dengan hasil penelitian bahwa secara simultan informasi arus kas dan laba bersih berpengaruh signifikan terhadap Volume Perdagangan Saham.

Artha et all (2013) meneliti Analisis Fundamental, Teknikal dan Makroekonomi Harga Saham Sektor Pertanian dengan hasil penelitian bahwa faktor Book Value per Share (BVS), Price to Book Value (PBV), Debt to Equity Ratio (DER), Tren Harga Saham, BI rate, Harga Minyak Dunia, dan Kurs Rupiah memberikan pengaruh signifikan terhadap Harga Saham sektor pertanian.

Siregar dan Fatimah (2013) meneliti Analisis Pengaruh Faktor Fundamental terhadap Return Saham Perbankan dengan hasil penelitian bahwa secara bersama-sama Return On Asset (ROA), Return On Equity (ROE), Net Interest Margin (NIM), Debt to Equity Ratio (DER) dan Loan To Deposit Ratio (LDR), mempunyai pengaruh yang signifikan terhadap Return Saham perbankan.

Jiwandono (2014) meneliti Analisis Faktor Fundamental Terhadap Harga Saham Sektor Perbankan yang Go Public di Indeks Kompas 100 dengan hasil penelitian bahwa Earning Per Share, Return On Aset, Return On Equity, Return On Investment, Asset Growth dan Capital Adequacy Ratio berpengaruh terhadap Harga Saham perusahaan.

Setelah mengetahui hasil beberapa penelitian tersebut di atas, langkah selanjutnya menguraikan implikasi kebijakan yang dapat digunakan oleh pihak-pihak yang berkepentingan terutama bagi investor dan manajemen bahwa faktor fundamental yang tersaji dari laporan keuangan sangat diperlukan, khususnya bagi para investor sebagai sinyal positif untuk menilai return saham yang dapat dijadikan pilihan sebelum memutuskan investasi.

Untuk pengembangan penelitian ini, maka perlu mengembangkan metode analisis teknikal yang mengakumulasikan harga dan volume perdagangan saham dengan menggunakan indikator analisa teknikal pada sistem penunjang keputusan dalam melakukan proses valuasi saham.

Usman et all (2012) meneliti Analisis Akurasi Bearish Versus Bullish dengan menggunakan Candlestick Analysis: Studi Empiris terhadap Indeks Saham Lq45 (19992012) dengan hasil penelitian yang menggunakan metode "Hendras candle function" yang memasukan nilai open (pembukaan), high (tertinggi), low (terendah), close (penutupan) selama periode pengamatan dari tahun 1999-2012, maka diperoleh 28 bulan indikasi yang menunjukkan terjadinya fenomena bearish dan juga bullish. Indikasi fenomena tersebut terbagi menjadi 12 bulan indikasi pola bearish dan 16 bulan kemunculan fenomena bullish. Temuan lain mengenai hipotesis bahwa tidak terdapat perbedaan signifikan antara harga prediksi Indeks LQ45 dengan menggunakan analisis candlestick dan harga aktual Indeks LQ45. 
Waworuntu dan Suryanto (2010) meneliti The Complementary Nature Of Fundamental And Technical Analysis menunjukkan analisis fundamental dan teknikal secara terpisah memiliki kemampuan untuk dapat memperkirakan pergerakan harga saham. Namun dengan menggabungkan kedua analisis ini dalam sebuah model dapat memberikan kemampuan prediksi yang lebih kuat. Pada Pasar saham Indonesia, analisa teknikal memiliki kemampuan yang lebih baik dalam memperkirakan harga saham kedepannya.

Zulkarnain (2012) meneliti akurasi grafik main chart dalam prediksi harga saham harian: kasus the winnest dan the losest menunjukkan bahwa analisis fundamental keuangan perusahaan emiten terbukti sinkron dengan hasil analisis teknikal meskipun dalam jangka pendek. Saham yang memiliki fundamental kuat, meskipun mengalami penurunan harga sesaat dalam jangka panjang akan terjadi dominasi kenaikan harga yang terus menerus. Isu negatif berdampak lebih besar terhadap saham yang fundamental lemah sehingga dari hasil pengamatan membuktikan bahwa prediksi yang dibuat berdasarkan grafik main chart dapat digunakan secara efektif, terutama pada saham-saham yang fundamental keuangannya kuat.

Ayanoglu (2013) Faculty Of Science And Letter Graduation Project. Istanbul Technical University meneliti Mathematical Back Ground Of Technical Indicator And Their Applications melakukan analisa teknikal masa lalu dan sekarang, ketika pedagang pasar keuangan membuat keputusan pembelian dan penjualan untuk mendorong/membantu investor dalam menghitung harga masa depan dengan mempelajari arah harga dengan informasi keuangan historis. Data yang digunakan adalah harga dan volume perdagangan saham di pasar Amerika Down Jones Industrial Average (DJIA). Analisa teknikal ini dikenal sebagai analis grafik harga dan volume sebagai titik awal dari Down Theory yang dikembangkan charles down pada awal tahun 1900 dan dianggap sebagai salah satu indikator penting bagi pasar amerika karena saat ini ada banyak matematikawan dan fisikawan dan mereka bekerja pada topik ini berdasarkan minat dan analisis. Analisa teknis pasar saham telah menjadi penting dalam latar belakang matematika untuk kontribusi ilmuwan. Dalam studi ini variabel yang disertakan antara lain indikator Bolinger Bands (BOLL), Moving Average (MACD), Relative Strength Indeks (RSI) dan Accumulation Distribution Line (ACDL).

Alwiyah dan Liyanto (2012) dalam penelitian Analisis Teknikal untuk mendapatkan Profit dalam Forex Trading Online. Tujuan penelitian ini adalah untuk menemukan konsistensi menguntungkan dalam memprediksi pergerakan harga, terutama pada pasangan GBPUSD dan EURUSD menggunakan teori Candlestick, Moving Average Convergence Divergence (MACD) dan Sthocastic Oscillator sebagai bagian dari analisis teknis sebelum mengambil tindakan apakah akan membeli atau menjual valuta asing. Laba dihitung untuk setiap sinyal jual-beli yang diberikan setelah mempertimbangkan biaya transaksi dalam jumlah penyebaran. Desain dari penelitian eksperimental dilakukan dengan menerapkan teori candlestick, MACD dan Osilator Stokastik pada forex trading untuk intra-hari perdagangan dengan timefame per jam, dan dilakukan sejak 13 Juni 2011 sampai 8 Juli 2011. Meskipun percobaan diuji dengan uang virtual dan berakhir kehilangan $1,8 \%$ dari saldo, penelitian menunjukkan inkonsistensi keuntungan menggunakan analisis teknis dengan Candlestick, MACD, Stochastic Oscillator dapat menguntungkan sekitar 60\%. Sebagai saran saya untuk penelitian berikutnya adalah memodifikasi indikator berdasarkan gaya perdagangan dan menemukan strategi yang baik seperti menggunakan Bollinger Bands dan volume, memiliki manajemen uang yang baik, dan harus disiplin menggunakan strategi. 
Prinsip analisa teknikal yaitu market price discount everything yaitu semua peristiwa dapat berpengaruh terhadap harga saham yang tercermin pada harga saham dikarenakan harga pasar saham ditentukan oleh permintaan dan penawaran pelaku pasar yang juga bersifat ekonomis dan non ekonomis dengan prinsip lainnya yaitu price moves in trend dengan prinsip jangan mengambil keputusan transaksi yang melawan tren harga. Sedangkan Analisa fundamental percaya bahwa investor dapat menciptakan peluang profitable dengan mengisolasi dan mengukur informasi tentang pasar, industri dan juga individu perusahaan yang belum dimanfaatkan dan ditemukan. Sedangkan analisa teknikal biasanya digunakan pedagang jangka pendek yang kepentingannya pada capital gain. Faktor dan kondisi diamati di pasar yang berbeda dari orang-orang fundamentalis. Oberlechner (2001) mengenai analisis teknis ada 59\% dari pedagang menggunakan chartist atau analisis teknis. Analisis teknis lebih populer digunakan investor, sebagian besar dari mereka menggunakan hanya data harga dan volume karena mudah, cepat diperoleh, disimpan dan dimanfaatkan.

Analisis teknis memiliki peran penting dalam penelitian analis untuk saham dalam pergerakan harga. Analisis teknis untuk mengisolasi satu pendekatan sepenuhnya dari lainnya. Teknis biasanya menyadari faktor fundamental dan fundamentalis juga menyadari kondisi pasar, tren, dan volume perdagangan. Analisis teknis yang dikenal pendekatan teknikal ini sebagai salah satu faktor untuk membuat keputusan. Pengakuan kemampuan harga masa lalu dan gerakan untuk memprediksi nilai masa depan yang ditulis pada Dow Theory diterbitkan di The Wall Street Journal oleh Charles Dow tahun 1900-1902 yang ditulis oleh Szabo (2004) yang secara implisit menyatakan bahwa harga masa lalu dapat meramalkan harga di masa depan.

Dengan fakta-fakta penelitian tentang dasar analisis teknis, maka peneliti akan membangun sebuah model penilaian yang mengintegrasikan kedua jenis analisis untuk mengakui kemampuan dalam menjelaskan harga saham. Penelitian ini difokuskan pada membangun sebuah model penilaian yang terdiri dari faktor fundamental dan teknis. Adapun pengujian ini memiliki sifat saling melengkapi dalam menjelaskan pergerakan harga saham di Indonesia.

Berdasarkan latar belakang tersebut maka peneliti tertarik untuk: (1) Mengetahui gambaran penerapan kinerja keuangan profitable dan analisa teknikal yaitu total asset turn over, return on asset, return on equity dan accumulation distribution line di Perusahaan terbuka yang terdaftar di Bursa Efek Indonesia. Perusahaan terbuka yang menerapkan dan menunjukan profitable untuk melangsungkan hidupnya. Analisa teknikal mencerminkan pergerakan harga dan volume perdagangan saham yang terjadi merupakan pengaruh dari perubahan permintaan dan penawaran pengambilan keputusan investor karena interpretasi atau analisa keadaan kinerja dan perkembangan keuangan suatu perusahaan. (2) Menjelaskan pengaruh kinerja keuangan profitable terhadap analisa teknikal yaitu total asset turn over, return on asset, return on equity terhadap accumulation distribution line baik secara bersama-sama maupun individu di Perusahaan terbuka yang terdaftar di Bursa Efek Indonesia.

\section{KAJIAN TEORI}

Meek et.al (1995) memeriksa pengungkapan secara sukarela berdasarkan tipe informasinya. Meek et.al mengklasifikasikan pengungkapan sukarela menjadi tiga grup yakni informasi stratejik, informasi keuangan/finansial dan informasi nonfinansial. Tipe 
informasi stratejik, informasi keuangan/finansial bagi investor memiliki relavansi pengambilan keputusan yang nyata dan tipe informasi nonfinansial lebih banyak diarahkan kepada akuntanbilitas sosial suatu Perusahaan dan ditujukan kepada pihak-pihak yang berkepentingan lebih luas lagi dari pada hanya kepada pemilik Perusahaan /investor.

Penelitian ini menggunakan objek perusahaan semen yang terdaftar di Bursa Efek Indonesia karena Perusahaan tersebut mampu bertahan ditengah terpaan krisis dengan mempertahankan dan meningkatkan penjualan secara langsung akan meningkatkan laba sehingga sahamnya dapat diminati oleh investor. Perusahaan semen juga termasuk peringkat saham Cyclical Stocks yang merupakan saham perusahaan yang memiliki keuntungan berfluktuasi karena dipengaruhi siklus usaha. Apabila kondisi bisnis membaik, keuntungan perusahaan akan membaik dan meningkat. Sejalan dengan saham perusahaan mengalami kenaikan. Sebaliknya jika iklim usaha kembali memburuk akan mengalami penurunan drastis dan keuntungannya akan memburuk, di Amerika Serikat misalnya industri yang dikategorikan sebagai berfluktuasi antara lain semen, industri baja, mesin-mesin, timah, otomotif, kontruksi dan real estate.

Pada tahun 1997-2002, mengalami kemerosotan setelah krisis moneter berdampak terhadap seluruh aspek kehidupan. Dampak krisis ini masih berlanjut sampai tahun 2007 yaitu salah satu Bank BNP Paribas mengumumkan pembekuan beberapa sekuritas yang terkait dengan kredit perumahan berisiko tinggi AS (subprime mortgage). Pembekuan ini mulai memicu gejolak di pasar finansial dan akhirnya merambat diseluruh dunia di penghujung triwulan III tahun 2008, intensitas krisis semakin besar seiring bangkrutnya bank investasi terbesar AS Lehman Brother yang diikuti oleh kesulitan keuangan disejumlah lembaga keuangan lainnya di AS, Eropa dan Jepang.

Tahun 2006, ketika pertumbuhan Gross Domestic Product (GDP) diperkirakan bertumbuh 6,2 \% dengan ditenggarai pemicu utama adalah sektor investasi, saham saham semen diprediksi akan menjadi bintang hampir sama dengan ketika awal tahun 2005 pada saat musibah kemanusiaan yaitu tsunami yang dialami masyarakat Aceh, beberapa saham sektor tetap menjadi diminati oleh investor. Oleh karena itu yang menyebabkan selain saham Consumer good adalah saham semen yang menjadi bagian dari saham manufaktur untuk menunjang infrastruktur akan selalu menjadi instrumen investasi yang menarik, tidak ada istilah bullish ataupun bearish, everytime is a good time for investment sehingga industri selalu menempati ruang tersendiri dalam perekonomian dan Pasar modal.

Perusahaan semen merupakan salah satu industri manufaktur basic industry yang mempunyai kontribusi besar terhadap pertumbuhan ekonomi Indonesia. Dalam keadaan krisis perusahaan telah memberikan indikasi kuat terhadap industri manufaktur yang mengalami kemerosotan produksi karena tergantung pada bahan baku impor, sehingga industri manufaktur tidak mampu bertahan ditengah terpaan krisis. Kondisi seperti ini pertanyaan paling relevan yang kemudian muncul adalah seberapa jauh krisis akan mempengaruhi industri manufaktur. Dalam situasi perekonomian global persaingan perusahaan untuk melakukan kegiatan ekonomi menjadi sangat ketat.

Dalam menghadapi kondisi yang demikian setiap perusahaan dituntut mampu membaca dan melihat situasi yang terjadi sehingga dalam melaksanakan fungsi-fungsi manajemen yang baik seperti dalam bidang pemasaran, produksi, sumber daya manusia maupun keuangan perusahaan dapat lebih unggul dalam persaingan yang ada. Hal ini terlihat jelas dari kondisi penjualan perusahaan semen yang meningkat. Peningkatan penjualan akan mengalami pertumbuhan yang baik sehingga berdampak terhadap 
peningkatan laba bersih pada akhirnya perusahaan mempunyai kemampuan untuk mempertahankan kelangsungan hidupnya dan memberikan dividen kepada para pemegang saham. Disamping itu peran industri semen bagi pembangunan nasional menjadi tulang punggung perekonomian, baik negara maju maupun berkembang sepanjang zaman, tidak saja disaat baik tetapi dalam keadaan sulit. Ketika pertumbuhan ekonomi menunjang tren positif, maka peningkatan infrastruktur terus dilakukan untuk menunjang daya dukung perekonomian. Sebaliknya pada saat masalah atau dalam contoh ekstrem saat bencana datang, peran industri semen bukan melemah justru semakin vital dan kritikal karena merupakan kunci kontinuitas kehidupan dapat dilakukan dengan pembangunan dan penataan kembali sarana-sarana umum dan infrastruktur yang rusak. Salah satu perusahaan semen yaitu PT Semen Gresik Tbk pada tahun 2007 yang mengalami pemecahan saham 1:10. Stock split lebih dimaknai positif ketimbang negatif, pertama aktivitas ini akan membuat saham perusahaan lebih murah dan menarik investor. Alasan berikutnya sesuatu yang lebih penting, stock split ini adalah sebuah apresiasi dan penerimaan pasar atas kinerjanya.

Dalam konteks ini sebagai seorang praktisi dan pengamat pasar modal untuk mengamati sekilas balik bahwa semen gresik kiprahnya di pasar modal karena stock split bermakna jauh lebih besar ketimbang sekedar pecah, tetapi mengandung nilai besarnya peran bagi perekonomian terutama di pasar modal Indonesia yang saat ini dapat kita amati telah berkembang dengan pesat.

Berdasarkan uraian fenomena pada penelitian ini, peneliti memilih menggunakan data penjualan, laba bersih, total aktiva dan total ekuitas untuk memperoleh rasio profitabilitas seperti total asset turn over, return on asset, return on equity yakni menganalisis pengaruh kinerja keuangan perusahaan terhadap analisis teknikal.

Analisis teknikal dalam penelitian ini adalah accumulation distribution line sebagai satu alat analisis pergerakan volume paling popular menganalisa aliran uang karena gagasan dari metode ini bahwa pergerakan volume akan selalu mendahului pergerakan harga sehingga dapat memprediksi arah pergerakan volume maka akan memperoleh indikasi lebih awal dibandingkan pihak lain dalam hal arah pergerakan harga dimasa akan datang. Dalam metode accumulation distribution line membutuhkan harga saham sebagai indikator untuk mengkonfirmasi kekuatan (strength) dan kestabilan dibalik trend pergerakan harga dan volume yang mampu mengindentifikasi kenaikan atau penurunan volume transaksi pada suatu saham.

Dari pembahasan pada beberapa hasil penelitian, secara konsep dapat disimpulkan bahwa analisis fundamental sangat tepat untuk menganalisa investasi jangka panjang dan menilai kelayakan harga saham. Bagaimana dengan analisa teknikal. Analisa teknikal didesain untuk menganalisis suatu investasi jangka pendek dengan membantu memberikan sinyal transaksi. Disamping itu analisis teknikal ini dapat digunakan untuk menentukan tren jangka panjang dari data masa lalu. 
Model Penelitian dapat disajikan pada Gambar 1.

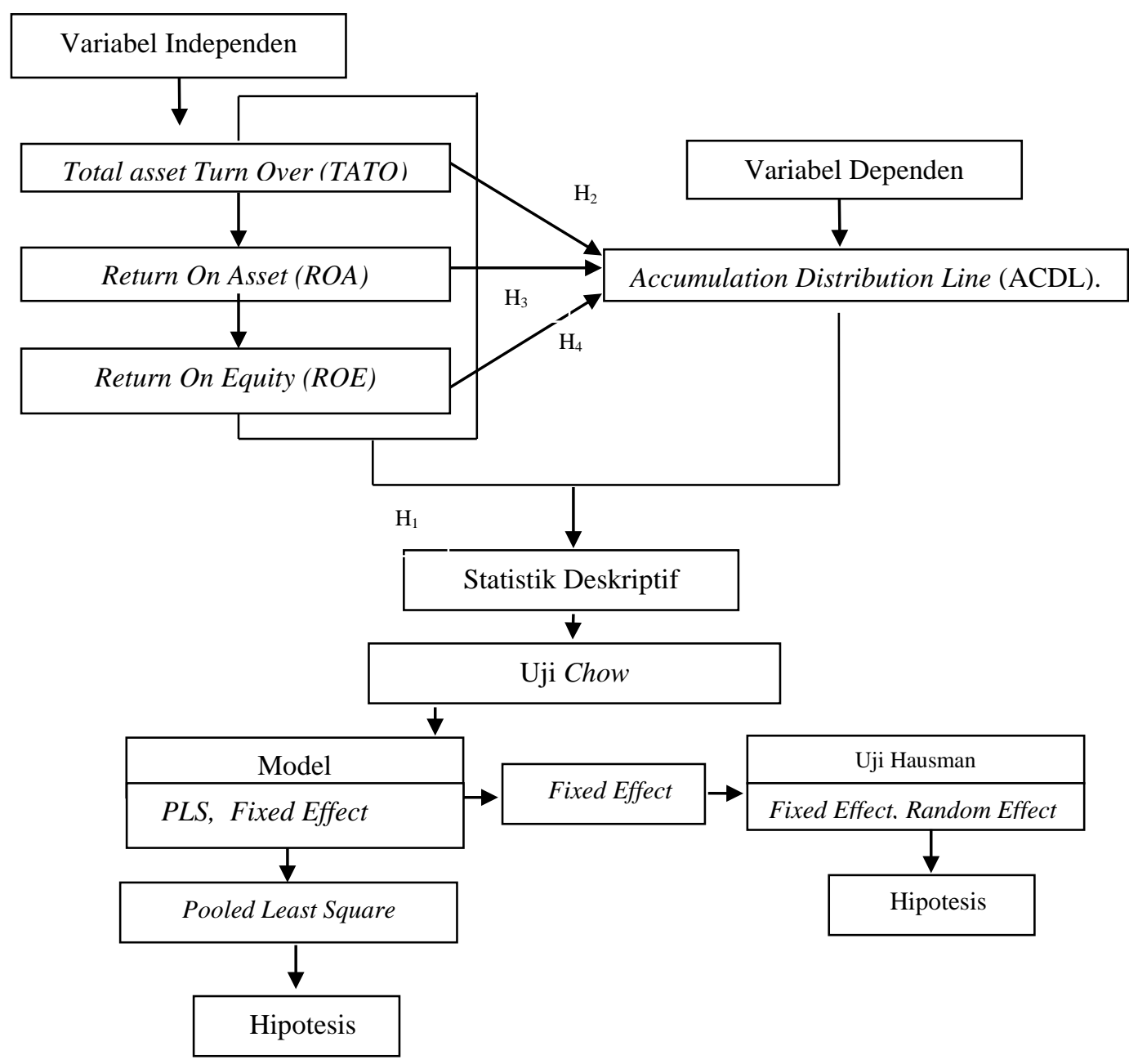

Gambar 1. Model Penelitian

Hipotesis: Menganalisis rasio profitabilitas seperti total asset turn over, return on asset, return on equity pengaruh terhadap analisis teknikal Accumulation Distribution Line, maka harus dilakukan tiga hal sebagai berikut:

1. Penilaian kelayakan model regresi dimana hipotesanya adalah:

Ada pengaruh yang nyata antara klasifikasi yang diprediksi dengan klasifikasi yang diamati

2. a. Penilaian chow model fit dimana hipotesanya adalah:

$\mathrm{H}_{0}$ : Model yang dihipotesakan cocok dengan Pool Least Square

$\mathrm{H}_{\mathrm{a}}$ : Model yang dihipotesakan cocok dengan Fixed Effect

b. Penilaian hausman model fit dimana hipotesanya adalah:

$\mathrm{H}_{0}$ : Model yang dihipotesakan cocok dengan Random Effect

$\mathrm{H}_{\mathrm{a}}$ : Model yang dihipotesakan cocok dengan Fixed Effect 
3. Pengujian koefisien regresi dimana berdasarkan uraian konsep dan teori dari berbagai rujukan serta kerangka teoritis yang Peneliti coba kembangkan, maka hipotesis yang ingin diuji adalah pengaruh Total Aset, ROA, REE terhadap Accumulation.

1. Total Asset Turn Over, ROA, ROE berpengaruh terhadap Accumulation Distribution Line.

2. Total Asset Turn Over berpengaruh terhadap Accumulation Distribution Line.

3. Return On Asset berpengaruh terhadap Accumulation Distribution Line.

4. Return On Equity berpengaruh terhadap Accumulation Distribution Line.

Dalam ketiga hal (penilaian kelayakan model regresi, penilaian chow model fit dan pengujian koefisien regresi) terus dilakukan sampai diperoleh model yang layak dan fit serta variabel independent yang signifikan atau memiliki pengaruh dan dapat memprediksi tren harga dan volume perdagangan saham yang tercermin pada accumulation distribution line.

\section{METODE}

Desain Penelitian. Metode penelitian yang digunakan dalam penelitian ini adalah metode deskriptif kausal (descriptive causal research). Metode secara deskriptif ini digunakan untuk menganalisa data dengan cara mendeskripsikan atau menggambarkan data yang telah terkumpul sebagaimana adanya tanpa bermaksud membuat kesimpulan yang berlaku umum atau generalisasi.

Adapun penelitian ini menggunakan deskriptif dengan diagram batang, agar dapat mengetahui perubahan baik kenaikan maupun penurunan pada setiap variabel. Sedangkan secara klausal ini berguna untuk mengetahui pengaruh variabel bebas (independent variable) yaitu total asset turn over, return on asset dan return on equity terhadap variabel terikat (dependent variable) yaitu accumulation distribution line. Dalam penelitian ini menggunakan data panel yang mengabungkan data time series dan cross section dengan analisa regresi linear berganda serta pengujiannya menggunakan analisis ekonometrika dan statistika.

Data dan penentuan sampel. Dalam rangka penelitian ini maka yang akan menjadi populasi adalah sekumpulan objek yang akan diteliti oleh peneliti ditujukan pada Perusahaan semen yang terdaftar di Bursa Efek Indonesia (BEI) diantaranya PT. Indocement Tunggal Prakasa Tbk, PT. Holcim Indonesia Tbk, PT. Semen Gresik (Persero) Tbk dan PT. Semen Baturaja (Persero) Tbk.

Teknik pengambilan sampel dalam penelitian ini adalah judgment sampling yang merupakan bentuk dari convenience sampling (sampling kemudahan), bila ditinjau dari cara-cara pengambilan sampelnya hampir sama dengan purposive sampling dalam teknik yang berdasarkan kreteria yang telah dirumuskan terlebih dahulu oleh peneliti. (Siagian dan Sugiarto, 2006: 120). Penelitian ini data yang digunakan adalah semua data yang memenuhi kriteria yang telah ditetapkan sebagai berikut:

a. Perusahaan semen diantaranya PT. Indocement Tunggal Prakasa Tbk, PT. Holcim Indonesia Tbk, dan PT. Semen Gresik (Persero) Tbk. Syarat untuk dapat terpilih adalah perusahaan semen yang telah tercatat di Bursa Efek Indonesia (BEI) secara konsisten selama periode penelitian berlangsung tetap tercatat dan termasuk saham aktif diperdagangkan dari tahun 2003 - 2012. 
b. Data tentang harga saham dan volume perdagangan saham perusahaan selama masa penelitian tersedia diambil selama 2 (dua) bulan setelah laporan keuangan diaudit dari tahun 2004 - 2013.

Dalam mengemukakan syarat menetapkan jumlah sampel menurut Roscoe (1975) yang dikutip oleh Sekaran (2006: 160) yaitu ukuran sampel yang tepat untuk penelitian lebih dari 30 dan kurang dari 500. Adapun yang dikembangkan para ahli secara umum untuk penelitian korelasional agar memperoleh hasil yang baik berjumlah sampel minimal 30, sedangkan penelitian eksperimen minimal 15.

Berdasarkan kriteria tersebut diperoleh 3 (tiga) Perusahaan, maka daftar perusahaan dalam sampel penelitian adalah pada PT. Indocement Tunggal Prakasa Tbk (INTP), PT. Holcim Indonesia Tbk (SMCB), PT. Semen Gresik (Persero) Tbk (SMGR).

Peneliti memilih menggunakan Perusahaan semen merupakan salah satu industri manufaktur basic industry yang mempunyai kontribusi besar terhadap pertumbuhan ekonomi Indonesia. Dalam keadaan krisis Perusahaan telah memberikan indikasi kuat terhadap industri manufaktur. Peneliti bermaksud agar Perusahaan semen dapat menjadi pilihan bagi para investor sebagai salah satu alternatif investasi yang di Pasar modal.

Pembaruan keputusan tersebut untuk memberikan informasi yang lebih cepat dan akurat kepada investor mengenai kondisi Emiten atau Perusahaan publik serta dalam rangka mengikuti Pasar modal global. Oleh karena itu tepat waktu merupakan suatu keharusan dalam publikasi laporan keuangan sehingga ada jaminan tentang relevansi informasi yang bersangkutan. Kemudian data harga dan volume perdagangan saham diambil dari awal bulan April sampai akhir bulan Mei tahun 2004- 2013 sebelum publikasi laporan keuangan triwulan I tahun selanjutnya.

Pengumpulan data yang digunakan adalah dengan cara penelitian kepustakaan (library research). Penelitian kepustakaan dilakukan dengan cara mengumpulkan data yang diperlukan melalui sumber-sumber tertulis seperti jurnal, skripsi, buku dan mempelajari modul perkuliahan yang berhubungan dengan masalah yang diteliti. Disamping itu peneliti menggunakan data sekunder adalah Indonesian Capital Market Directory (ICMD), laporan keuangan audit akhir tahun yang diperoleh dari situs Bursa Efek Indonesia dan harga serta volume perdagangan saham di Galeri Investasi Universitas Mercu Buana dan Valbury Asia Securities.

Pengukuran variabel dependent dan independent. Tabel 2 meringkas indikator yang digunakan untuk mengukur variabel dan sumber perolehan data. Beberapa indikator variabel adalah berupa data rasio dan interval.

Metode Analisa Data. Terdapat dua metode yaitu analisa deskriptif untuk mengetahui perubahan baik kenaikan maupun penurunan dalam setiap variabel dan persamaan regresi linear berganda. Dalam persamaan regresi, peneliti mengetahui bahwa berdasarkan syaratsyarat yang diasumsikan penaksir kuadrat kecil tanpa terkendala merupakan penaksir tak bias linear yang terbaik (BLUE). Sifat ini tetap berlaku untuk regresi berganda. Jadi setiap regresi yang ditaksir dengan metode least square bersifat linear dan tak bias secara ratarata. Koefisien yang ditaksir ini tepat sama dengan nilai yang sebenarnya. Penaksir least square memiliki varians yang mungkin paling kecil sehingga parameter yang sebenarnya dapat ditaksir secara lebih akurat karena bersifat efisien. (Gujarati, 2006: 200). 
Tabel 2. Variabel dependent dan independent, indicator dan sumber data

\begin{tabular}{|c|c|c|}
\hline No & $\begin{array}{l}\text { Variabel dependent } \\
\text { dan independent }\end{array}$ & Indikator \\
\hline \multirow[t]{5}{*}{1} & \multirow{4}{*}{$\begin{array}{l}\text { Variabel dependent } \\
\text { 1. Accumulation } \\
\text { Distribution Line }\end{array}$} & $C L V=\frac{(C-L)-(H-C)}{(H-L)}$ \\
\hline & & $\mathrm{ACDL}=\mathrm{CLV} \mathrm{t} \mathrm{X}$ Volume $\mathrm{t}$ \\
\hline & & ACDL $t=$ Yesterdays ACDL $+($ CLV t X Volume $t)$ \\
\hline & & $\begin{aligned} \mathbf{L} & -1 \text { sauga Luw paua penuue penzanatan } \\
\mathrm{C} & =\text { Harga Close pada periode pengamatan } \\
\mathrm{CLV} & =\text { Close Location Value }\end{aligned}$ \\
\hline & $\begin{array}{l}\text { Variabel independent } \\
\text { 1. Total Asset Turn } \\
\text { Over } \\
\text { 2. Return On Asset } \\
\text { 3. Return On Equity }\end{array}$ & $\begin{array}{l}\text { Sales / Total Aset x } 1 \text { kali } \\
\text { Net Profit After Tax/ Total Asset } \\
\text { Net Profit After Tax / Total Equity }\end{array}$ \\
\hline
\end{tabular}

Pada data variabel independen memiliki data rasio dan variabel dependen sebagai data interval. Adapun persamaaan regresi linear berganda sebagai berikut:

$$
\mathrm{LOGACDL}=\mathrm{B}_{1}+\mathrm{B}_{2} \mathrm{TATO}+\mathrm{B}_{3} \mathrm{ROA}+\mathrm{B}_{4} \mathrm{ROE}+\mu_{\mathrm{t}}
$$

Analisa regresi linear berganda untuk menaksir regresi dengan metode bersifat linear dan tak bias secara rata- rata yang menentukan model persamaan agar mengetahui hubungan fungsional antara Total Asset Turn Over, Return On Asset dan Return On Equity (terhadap Accumulation Distribution Line yang diformulasikan dalam fungsi regresi.

\section{HASIL DAN PEMBAHASAN}

Uji Deskriptif. Statistik Deskriptif membahas cara pengumpulan data, penyederhanaan angka pengamatan yang diperoleh (meringkas dan menyajikan) serta melakukan pengukuran pemusatan dan penyebaran untuk memperoleh informasi yang lebih menarik, berguna dan lebih mudah dipahami. Data dapat disajikan mulai dari nilai terendah, tertinggi dan rata-rata. Penelitian ini juga menyajikan deskriptif dengan diagram batang untuk mengetahui perkembangan baik kenaikan maupun penurunan setiap variabel dan grafik indikasi trend bullish dan trend bearish. Penelitian ini dapat mengetahui ekses demand akan suatu saham meningkat disebabkan harga rendah maka perubahan jumlah saham yang diminta (demand) atau ekses supply akan suatu saham meningkat disebabkan harga tinggi maka perubahan jumlah saham yang ditawarkan (supply). Disamping itu kenaikan volume yang apakah searah dengan kenaikan harga.

Berdasarkan hasil perhitungan statistik deskriptif pada Tabel 3, telah menunjukkan jumlah $n$ adalah 10 data pada PT. Indocement Tunggal Prakasa Tbk yang memiliki Total Asset Turn Over dengan nilai rata-rata 0.671549 yang berarti 67.15 kali dalam setiap tahunnya dan nilai terendah 0.409823 berarti 40.98 kali tahun 2003 serta nilai tertinggi mencapai 0.866550 berarti 86.65 kali memiliki kemampuan dapat menghasilkan volume penjualan dengan tingkat penggunaan efisiensi aktiva tahun 2008. Sedangkan dalam Return On Asset dengan nilai rata-rata 0.128698 yang berarti $12.86 \%$ dalam setiap 
tahunnya dan nilai terendah 0.011874 berarti $1.87 \%$ tahun 2004 dan nilai tertinggi mencapai 0.210146 berarti $21.01 \%$ memiliki kemampuan menghasilkan keuntungan dengan seluruh penggunaan aktiva yang tersedia tahun 2010 .

Tabel 3. PT Indocement Tunggal Prakarsa Tbk dengan Rasio TATO, ROA dan ROE

\begin{tabular}{clcccccc}
\hline & \multicolumn{1}{c}{ Nama Emiten } & Kode & Tahun & TATO & ROA & ROE & ACDL \\
\hline No. & PT. Indocement Tunggal Prakarsa Tbk & INTP & 2003 & 0.409823 & 0.066070 & 0.147854 & 102700880 \\
2 & PT. Indocement Tunggal Prakarsa Tbk & INTP & 2004 & 0.472367 & 0.011874 & 0.024920 & 35736081 \\
3 & PT. Indocement Tunggal Prakarsa Tbk & INTP & 2005 & 0.530766 & 0.070203 & 0.131397 & 4498060 \\
4 & PT. Indocement Tunggal Prakarsa Tbk & INTP & 2006 & 0.659007 & 0.061761 & 0.098264 & 12121717 \\
5 & PT. Indocement Tunggal Prakarsa Tbk & INTP & 2007 & 0.729597 & 0.097640 & 0.142178 & 18364123 \\
6 & PT. Indocement Tunggal Prakarsa Tbk & INTP & 2008 & 0.866550 & 0.154651 & 0.205348 & -6172339 \\
7 & PT. Indocement Tunggal Prakarsa Tbk & INTP & 2009 & 0.796644 & 0.206884 & 0.257160 & 24711393 \\
8 & PT. Indocement Tunggal Prakarsa Tbk & INTP & 2010 & 0.725772 & 0.210147 & 0.246604 & 28948807 \\
9 & PT. Indocement Tunggal Prakarsa Tbk & INTP & 2011 & 0.765117 & 0.198416 & 0.228901 & 24072634 \\
10 & PT. Indocement Tunggal Prakarsa Tbk & INTP & 2012 & 0.759842 & 0.209332 & 0.245299 & 4085642 \\
& Rata-rata & & & 0.671549 & 0.128698 & 0.172793 & 24906700 \\
\hline
\end{tabular}

Return On Equity dengan nilai rata-rata 0.172793 yang berarti $17.27 \%$ dalam setiap tahunnya dan nilai terendah 0.024920 berarti $2.49 \%$ tahun 2004 dan nilai tertinggi mencapai 0.257159 berarti $25.71 \%$ memiliki kemampuan menghasilkan keuntungan dengan seluruh penggunaan modal yang tersedia tahun 2009. Oleh karena itu dapat diketahui bahwa nilai terendah yang lebih kecil dibandingkan dengan nilai rata-rata, maka mencerminkan kondisi yang mengalami rata-rata kenaikan dalam setiap rasio yang digunakan dalam masa pengamatan.

Dalam perhitungan statistik deskriptif, telah menunjukkan jumlah $n$ adalah 10 data pada PT. Indocement Tunggal Prakasa Tbk yang memiliki Accumulation Distribution Line (ACDL) IMQ dengan nilai rata-rata 24906700 lembar dalam setiap tahunnya dan nilai terendah (-6172339) tahun 2009 dan nilai tertinggi mencapai 102700880 lembar yang berarti pergerakan aktivitas volume perdagangan saham mengindikasikan pada trend bullish tahun 2004. Oleh karena itu dapat diketahui bahwa nilai terendah yang lebih kecil dibandingkan dengan nilai mean, maka mencerminkan kondisi yang mengalami rata-rata kenaikan dalam setiap Accumulation Distribution Line yang digunakan dalam masa pengamatan.

Tabel 4. PT Holcim Indonesia Tbk dengan Rasio TATO, ROA dan ROE

\begin{tabular}{cccccccc}
\hline No. & Nama Emiten & Kode & Tahun & TATO & ROA & ROE & ACDL \\
\hline 1 & PT. Holcim Indonesia Tbk & SMCB & 2003 & 0.292939 & 0.022767 & 0.065530 & 207449450 \\
2 & PT. Holcim Indonesia Tbk & SMCB & 2004 & 0.314942 & -0.070891 & -0.247558 & 103018919 \\
3 & PT. Holcim Indonesia Tbk & SMCB & 2005 & 0.412003 & -0.045613 & -0.181326 & 185811218 \\
4 & PT. Holcim Indonesia Tbk & SMCB & 2006 & 0.423615 & 0.024901 & 0.083837 & 431787165 \\
5 & PT. Holcim Indonesia Tbk & SMCB & 2007 & 0.520918 & 0.023502 & 0.075048 & 216873836 \\
6 & PT. Holcim Indonesia Tbk & SMCB & 2008 & 0.650635 & 0.034379 & 0.100640 & 129728837 \\
7 & PT. Holcim Indonesia Tbk & SMCB & 2009 & 0.818112 & 0.123291 & 0.270220 & 71582086 \\
8 & PT. Holcim Indonesia Tbk & SMCB & 2010 & 0.571088 & 0.079372 & 0.121423 & 152048773 \\
9 & PT. Holcim Indonesia Tbk & SMCB & 2011 & 0.687089 & 0.096341 & 0.140156 & 71898267 \\
10 & PT. Holcim Indonesia Tbk & SMCB & 2012 & 0.740524 & 0.113523 & 0.164100 & -1455190 \\
& Rata-rata & & & 0.543187 & 0.040157 & 0.059207 & 156874336 \\
\hline
\end{tabular}


Berdasarkan hasil perhitungan statistik deskriptif pada Tabel 4, telah menunjukkan jumlah $n$ adalah 10 data pada PT. Holcim Indonesia Tbk yang memiliki Total asset Turn Over dengan nilai rata-rata 0.543186 yang berarti 54.31 kali dalam setiap tahunnya dan nilai terendah 0.292939 berarti 29.29 kali tahun 2003 serta nilai tertinggi mencapai 0.818111 berarti 81.81 kali memiliki kemampuan dapat menghasilkan volume penjualan dengan tingkat penggunaan efisiensi aktiva tahun 2009. Sedangkan dalam Return On Asset dengan nilai rata-rata 0.040157 yang berarti $4.01 \%$ dalam setiap tahunnya dan nilai terendah (0.070891 ) berarti -7.08 \% tahun 2004 serta nilai tertinggi mencapai 0.123290 berarti 12.32 $\%$ memiliki kemampuan menghasilkan keuntungan dengan seluruh penggunaan aktiva yang tersedia tahun 2009.

Return On Equity dengan nilai rata-rata 0.05920 yang berarti $5.92 \%$ dalam setiap tahunnya dan nilai terendah $(-0.247557)$ berarti $-24.75 \%$ tahun 2004 dan nilai tertinggi mencapai 0.270220 berarti $27.02 \%$ memiliki kemampuan menghasilkan keuntungan dengan seluruh penggunaan modal yang tersedia tahun 2009. Oleh karena itu dapat diketahui bahwa nilai terendah yang lebih kecil dibandingkan dengan nilai rata-rata, maka mencerminkan kondisi yang mengalami rata- rata kenaikan dalam setiap rasio yang digunakan dalam masa pengamatan.

Dalam perhitungan statistik deskriptif, telah menunjukkan jumlah $n$ adalah 10 data pada PT. Holcim Indonesia Tbk yang memiliki Accumulation Distribution Line (ACDL) IMQ dengan nilai rata-rata 156874336 lembar dalam setiap tahunnya dan nilai terendah (1455190) tahun 2013 dan nilai tertinggi mencapai 431787165 lembar yang berarti pergerakan aktivitas volume perdagangan saham mengindikasikan pada trend bullish tahun 2007. Oleh karena itu dapat diketahui bahwa nilai terendah yang lebih kecil dibandingkan dengan nilai mean, maka mencerminkan kondisi yang mengalami rata- rata kenaikan dalam setiap Accumulation Distribution Line yang digunakan dalam masa pengamatan.

Tabel 5. PT Semen Gresik (Persero) Tbk dengan Rasio TATO, ROA dan ROE

\begin{tabular}{cccccccc}
\hline No. & \multicolumn{1}{c}{ Nama Emiten } & Kode & Tahun & TATO & ROA & ROE & ACDL \\
\hline 1 & PT. Semen Gresik Tbk & SMGR & 2003 & 0.818850 & 0.060001 & 0.113574 & 1083508 \\
2 & PT. Semen Gresik Tbk & SMGR & 2004 & 0.910248 & 0.076347 & 0.139719 & -473575 \\
3 & PT. Semen Gresik Tbk & SMGR & 2005 & 1.032112 & 0.137269 & 0.224264 & -417868 \\
4 & PT. Semen Gresik Tbk & SMGR & 2006 & 1.164270 & 0.172819 & 0.235566 & -1393434 \\
5 & PT. Semen Gresik Tbk & SMGR & 2007 & 1.127486 & 0.208498 & 0.267895 & -16746808 \\
6 & PT. Semen Gresik Tbk & SMGR & 2008 & 1.151550 & 0.238004 & 0.312723 & 10106250 \\
7 & PT. Semen Gresik Tbk & SMGR & 2009 & 1.110919 & 0.256846 & 0.326201 & 125469190 \\
8 & PT. Semen Gresik Tbk & SMGR & 2010 & 0.921685 & 0.233452 & 0.302606 & 49399100 \\
9 & PT. Semen Gresik Tbk & SMGR & 2011 & 0.833034 & 0.201167 & 0.270629 & 68818692 \\
10 & PT. Semen Gresik Tbk & SMGR & 2012 & 0.737356 & 0.185358 & 0.271218 & -45612584 \\
& Rata-rata & & & 0.980751 & 0.176976 & 0.246439 & 19023247 \\
\hline
\end{tabular}

Berdasarkan hasil perhitungan statistik deskriptif pada Tabel 5, telah menunjukkan jumlah $n$ adalah 10 data pada PT. Semen Gresik Tbk yang memiliki Total Asset Turn Over dengan nilai rata-rata 0.980751 yang berarti 98.07 kali dalam setiap tahunnya dan nilai terendah 0.737356 berarti 73.73 kali tahun 2012 serta nilai tertinggi mencapai 1.164270 berarti 116.42 kali memiliki kemampuan dapat menghasilkan volume penjualan dengan tingkat penggunaan efisiensi aktiva tahun 2006. Sedangkan dalam Return On Asset dengan 
nilai rata-rata 0.176976 yang berarti $17.69 \%$ dalam setiap tahunnya dan nilai terendah 0.060001 berarti $6.00 \%$ tahun 2003 dan nilai tertinggi mencapai 0.256845 berarti $25.68 \%$ memiliki kemampuan menghasilkan keuntungan dengan seluruh penggunaan aktiva yang tersedia tahun 2009.

Return On Equity dengan niali rata-rata 0.246439 yang berarti $24.64 \%$ dalam setiap tahunnya dan nilai terendah 0.113574 berarti $11.35 \%$ tahun 2003 dan nilai tertinggi mencapai 0.326200 berarti $32.62 \%$ memiliki kemampuan menghasilkan keuntungan dengan seluruh penggunaan modal yang tersedia tahun 2009. Oleh karena itu dapat diketahui bahwa nilai terendah yang lebih kecil dibandingkan dengan nilai rata-rata, maka mencerminkan kondisi yang mengalami rata- rata kenaikan dalam setiap rasio yang digunakan dalam masa pengamatan.

Dalam perhitungan statistik deskriptif, telah menunjukkan jumlah $n$ adalah 10 data pada PT. Semen Gresik (Persero) Tbk yang memiliki Accumulation Distribution Line (ACDL) IMQ dengan nilai rata-rata 19023247 lembar dalam setiap tahunnya dan nilai terendah (-45612584) tahun 2013 dan nilai tertinggi mencapai 125469190 yang berarti pergerakan aktivitas volume perdagangan saham mengindikasikan pada trend bullish tahun 2010. Oleh karena itu dapat diketahui bahwa nilai terendah yang lebih kecil dibandingkan dengan nilai rata-rata, maka mencerminkan kondisi yang mengalami ratarata kenaikan dalam setiap Accumulation Distribution Line yang digunakan dalam masa pengamatan.

PT. Indocement Tunggal Prakarsa Tbk, PT. Holcim Indonesia Tbk dan PT. Semen Gresik (Persero) Tbk menunjukan harga akan turun akhir bulan Mei tahun 2013 yang berarti harga penutupan lebih rendah dari pada harga pembukaan, maka digambarkan dengan balok berwarna merah yang berindikasi tren bearish. Pembentukan resistance merupakan kebalikan dari support dimana tekanan jual sangat besar yang mengalahkan minat beli akibatnya kenaikan harga sementara akan tertahan dan cenderung turun dapat disebut juga down trend berarti harga saham sedang dalam kondisi negatif, sebaiknya investor melakukan posisi beli atau mengambil keputusan beli sehingga dapat memperoleh keuntungan. Dengan kondisi harga saham negatif atau turun berarti jumlah saham yang diminta akan meningkat, maka akan adanya pembentukan support dimasa yang akan datang dimana tekanan beli sangat besar yang mengalahkan minat jual yang berdampak pada kenaikan harga saham.

Uji Model. Dalam memilih model regresi data panel terbaik antara model common effect yang disebut juga pool least square, model fixed effect atau model random effect, yaitu dengan uji Chow untuk menentukan model apakah menggunakan common effect atau fixed effect. Dasar pengambilan keputusan dapat ditunjukan dari nilai probabilitas yang lebih kecil dari 5\% berarti model yang paling tepat digunakan adalah fixed effect. Sebaliknya jika nilai probabilitas yang lebih besar dari 5\% berarti model yang paling tepat digunakan adalah common effect. Adapun jika menggunakan model fixed effects maka akan dilanjutkan dengan uji Hausman untuk menentukan apakah fixed effect atau random effect. Dasar pengambilan keputusan dapat ditunjukan dari nilai probabilitas yang lebih kecil dari $5 \%$ berarti model yang paling tepat digunakan adalah fixed effect. Sebaliknya jika nilai probabilitas yang lebih besar dari 5\% berarti model paling tepat digunakan adalah random effect. Hasil perhitungan Chow statistic disajikan pada Tabel 6. 
Tabel 6. Uji Chow

\begin{tabular}{lrrr}
\hline Effects Test & Statistic & d.f. & Prob. \\
\hline Cross-section F & -0.000000 & $(29,867)$ & 1.0000 \\
Cross-section Chi-square & 0.000000 & 29 & 1.0000 \\
\hline
\end{tabular}

Berdasarkan Tabel 6, menunjukkan nilai Chow statistic memiliki nilai signifikansi 1.0000 yang jauh lebih besar dari pada $5 \%$. Dengan demikian model yang paling tepat digunakan adalah common effect, maka peneliti tidak dapat menolak $\mathrm{H}_{0}$ yang berarti model ini dalam dimensi waktu maupun perilaku individu tidak berbeda berbagai kurun waktu dan dapat diasumsikan bahwa perilaku data antar perusahaan sama dalam berbagai rentang waktu.

Analisa Regresi Linear Berganda. Analisa regresi linear berganda untuk menaksir regresi dengan metode pooled least square bersifat linear dan tak bias secara rata- rata yang menentukan model persamaan agar mengetahui hubungan fungsional yang diformulasikan dalam fungsi regresi sebagai berikut (Gambar 2)

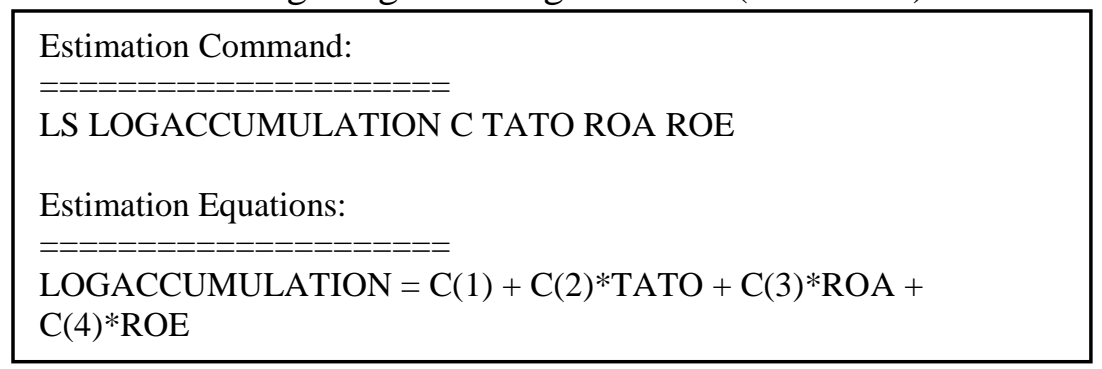

Gambar 2. Analisa Regresi Linear Berganda

Dari hasil output regresi pada gambar 1, maka dapat diperoleh hasil persamaan regresi sebagai berikut: LOG_Accumulation Distribution Line $=1.161347+7.710405$ Total Asset Turn Over -6.009515 Return On Asset - 0.017500 Return On Equity.

Dari hasil persamaan model regresi tersebut diperoleh:

1. Konstanta sebesar 1.161347 terdapat hubungan positif terhadap Accumulation Distribution Line. Hal ini menyatakan bahwa jika Total Asset Turn Over Return On Asset dan Return On Equity dianggap konstan, maka Accumulation Distribution Line sebesar 1.161347.

2. Koefisien regresi Total Asset Turn Over terdapat hubungan positif terhadap Accumulation Distribution Line sebesar 7.710405. Hal ini menyatakan bahwa setiap perubahan Total Asset Turn Over 1 \%, maka akan meningkatkan Accumulation Distribution Line sebesar 7.710405.

3. Koefisien regresi Return On Asset terdapat hubungan negatif terhadap Accumulation Distribution Line sebesar (-6.009515). Hal ini menyatakan bahwa setiap perubahan Return On Asset 1 \%, maka akan menurunkan Accumulation Distribution Line sebesar (-6.009515).

4. Koefisien regresi Return On Equity terdapat hubungan negatif terhadap Accumulation Distribution Line (-0.017500). Hal ini menyatakan bahwa setiap perubahan Return On Equity 1 \%, maka akan menurunkan Accumulation Distribution Line (-0.017500). 
Koefisien regresi yang menunjukkan hubungan positif ini menunjukan bahwa kenaikan harga diikuti dengan kenaikan volume yang merupakan indikasi trend bullish karena ekses demand akan suatu saham meningkat disebabkan harga rendah maka perubahan jumlah saham yang diminta (demand) semakin banyak sehingga dapat mempengaruhi kenaikan harga saham yang menyebabkan perubahan jumlah saham yang ditawarkan (supply) juga semakin banyak. Kenaikan volume searah dengan demand dan supply secara bersamaan meningkat yang mencerminkan banyaknya investor bersedia mengambil keputusan membeli dan menjual saham pada keseimbangan harga yang terbentuk di Pasar. Begitu halnya dengan koefisien regresi yang menunjukkan hubungan negatif ini menjelaskan bahwa kenaikan harga tidak diikuti dengan kenaikan volume sebagai indikasi trend bearish karena ekses demand akan suatu saham meningkat disebabkan harga rendah demand saham semakin dapat mempengaruhi kenaikan harga saham. Sedangkan kenaikan volume disebabkan demand saham meningkat dan jumlah saham ditawarkan (supply) cenderung tetap atau sedikit. Investor yang satu lebih banyak bersedia mengambil keputusan membeli, tetapi investor lainnya tidak bersedia melepas sahamnya (hold) yang disebabkan indikasi trend bearish harga rendah maka perubahan jumlah saham yang ditawarkan (supply) sedikit karena investor lainnya mengharapkan harga saham akan meningkat dimasa yang akan datang.

Menguji Hipotesis. Dalam menguji hipotesis untuk mendapatkan probabilitas, dimana peneliti dapat mengetahui tingkat probabilitas dengan cara menggunakan pendekatan memperoleh statistik uji yang relevan diantaranya:

a. Uji F (simultan). Pengujian ini dilakukan untuk melihat pengaruh signifikansi secara simultan dari variabel independen dalam model terhadap variabel dependen. Bila $F$ hitung $>F$ tabel berarti $\mathrm{H}_{0}$ ditolak dan $\mathrm{H}_{\mathrm{a}}$ diterima, jika berdasarkan probabilitas ( $p$ value) $<0,05$ berarti $\mathrm{H}_{0}$ ditolak dan $\mathrm{H}_{\mathrm{a}}$ diterima maka variabel independen secara simultan berpengaruh signifikansi terhadap variabel dependen. Sebaliknya bila $F$ hitung $<F$ tabel berarti $\mathrm{H}_{0}$ diterima dan $\mathrm{H}_{\mathrm{a}}$ ditolak, jika probabilitas ( $p$-value) $>0,05$ berarti $\mathrm{H}_{0}$ diterima dan $\mathrm{H}_{\mathrm{a}}$ ditolak maka tidak ada pengaruhnya. Hasil perhitungannya sebagai berikut:

Tabel 7. Pengaruh Total Asset Turn Over, ROA dan ROE terhadap Accumulation Distribution Line

\begin{tabular}{lrrrr}
\hline \multicolumn{1}{c}{ Variable } & Coefficient & \multicolumn{1}{c}{ Std. Error } & t-Statistic & Prob. \\
\hline \multicolumn{1}{c}{ C } & 1.161347 & 0.048704 & 23.84525 & 0.0000 \\
TATO & 7.710405 & 0.796445 & 9.681031 & 0.0000 \\
ROA & -6.009515 & 0.735256 & -8.173359 & 0.0000 \\
ROE & -0.017500 & 0.002132 & -8.207238 & 0.0000 \\
& & & & \\
R-squared & 0.386404 & Mean dependent var & 0.980751 \\
Adjusted R-squared & 0.380186 & S.D. dependent var & 0.148469 \\
S.E. of regression & 0.116887 & Akaike info criterion & -1.441966 \\
Sum squared resid & 4.044155 & Schwarz criterion & -1.392582 \\
Log likelihood & 220.2949 & Hannan-Quinn criter. & -1.422203 \\
F-statistic & 62.13414 & Durbin-Watson stat & 1.377274 \\
Prob(F-statistic) & 0.000000 & & \\
\hline
\end{tabular}


Berdasarkan pada Tabel 7, nilai $F$ hitung sebesar 62.13414 dan $F$ tabel sebesar 2.980, maka $F$ hitung $62.13414>F$ tabel 2.980 dengan nilai signifikansi $0.0000<0.05$. Hal ini berarti $\mathrm{H}_{0}$ ditolak dan $\mathrm{H}_{\mathrm{a}}$ diterima sehingga dapat dinyatakan bahwa Total Asset Turn Over, Return On Asset dan Return On Equity berpengaruh signifikan terhadap Accumulation Distribution Line.

b. Uji t (parsial). Pengujian ini dilakukan untuk melihat pengaruh signifikansi secara individu dari variabel independen dalam model terhadap variabel dependen. Bila $t$ hitung $>t$ tabel berarti $\mathrm{H}_{0}$ ditolak dan $\mathrm{H}_{\mathrm{a}}$ diterima, jika berdasarkan probabilitas ( $p$ value) $<0,05$ berarti $\mathrm{H}_{0}$ ditolak dan $\mathrm{H}_{\mathrm{a}}$ diterima maka variabel independen secara individu berpengaruh signifikansi terhadap variabel dependen. Sebaliknya bila $t$ hitung $<t$ tabel berarti $\mathrm{H}_{0}$ diterima dan $\mathrm{H}_{\mathrm{a}}$ ditolak, jika probabilitas ( $p$-value) $>0,05$ berarti $\mathrm{H}_{0}$ diterima dan $\mathrm{H}_{\mathrm{a}}$ ditolak maka tidak ada pengaruhnya. Hasil perhitungannya sebagai berikut:

Tabel 8. Pengaruh Total Asset Turn Over terhadap Accumulation Distribution Line

\begin{tabular}{ccccc}
\hline Variable & Coefficient & Std. Error & t-Statistic & Prob. \\
\hline & & & & \\
C & 0.806490 & 0.023044 & 34.99802 & 0.0000 \\
TATO & 0.984661 & 0.122555 & 8.034474 & 0.0000 \\
\hline
\end{tabular}

Berdasarkan pada Tabel 8, nilai $t$ hitung sebesar 8.034474 dan $t$ tabel sebesar 2.0484, maka $t$ hitung $8.034474>t$ tabel 2.0484 dengan nilai signifikansi $0.0000<0.05$. Hal ini berarti $\mathrm{H}_{0}$ ditolak dan $\mathrm{H}_{\mathrm{a}}$ diterima sehingga dapat dinyatakan bahwa Total Asset Turn Over berpengaruh positif signifikan terhadap Accumulation Distribution Line.

Tabel 9. Pengaruh Return On Asset terhadap Accumulation Distribution Line

\begin{tabular}{ccccc}
\hline Variable & Coefficient & Std. Error & t-Statistic & Prob. \\
\hline C & & & & \\
ROA & 0.774591 & 0.030176 & 25.66926 & 0.0000 \\
& 0.836554 & 0.118128 & 7.081740 & 0.0000 \\
\hline
\end{tabular}

Berdasarkan pada Tabel 9, nilai $t$ hitung sebesar 7.081740 dan $t$ tabel sebesar 2.0484, maka $t$ hitung $7.081740>t$ tabel 2.0484 dengan nilai signifikansi $0.0000<0.05$. Hal ini berarti $\mathrm{H}_{0}$ ditolak dan $\mathrm{H}_{\mathrm{a}}$ diterima sehingga dapat dinyatakan bahwa Return On Asset berpengaruh positif signifikan terhadap Accumulation Distribution Line.

Tabel 10. Pengaruh Return On Equity terhadap Accumulation Distribution Line

\begin{tabular}{crrrr}
\hline Variable & Coefficient & Std. Error & t-Statistic & Prob. \\
\hline C & & & & \\
ROE & 0.989802 & 0.012058 & 82.08332 & 0.0000 \\
& -0.002468 & 0.002313 & -1.066869 & 0.2869 \\
\hline
\end{tabular}


Berdasarkan pada Tabel 10, nilai $t$ hitung sebesar (-1.066869) dan $t$ tabel sebesar 2.0484, maka $t$ hitung $(-1.066869)<t$ tabel 2.0484 dengan nilai signifikansi $0.2869>0.05$. Hal ini berarti $\mathrm{H}_{0}$ diterima dan $\mathrm{H}_{\mathrm{a}}$ ditolak sehingga dapat dinyatakan bahwa Return On Equity tidak berpengaruh signifikan terhadap Accumulation Distribution Line.

Return On Equity merupakan rasio yang digunakan untuk mengukur penghasilan atau income yang tersedia bagi para pemilik Perusahaan (baik para pemegang saham biasa maupun preferen) atas modal yang mereka investasikan didalam perusahaan. Makin tinggi return atau penghasilan yang diperoleh semakin baik kedudukan pemilik perusahaan sehingga kondisi keuangan akan mempengaruhi pemikiran bagi pemegang saham, jika perusahaan memperoleh laba atau keuntungan karena modalnya berasal dari sumber pendanaan internal melalui modal sendiri, laba ditahan dan cadangan dana kas yang dimiliki oleh perusahaan. Disamping itu modal juga berasal dari sumber pendanaan eksternal melalui hutang kepada kreditor dan menjual saham serta menerbitkan obligasi. Perusahaan harus dapat menciptakan kombinasi yang paling menguntungkan antara penggunaan modal tersebut.

Struktur modal merupakan masalah yang sangat penting bagi perusahaan karena sebagai cerminan dari kondisi keuangan, apakah kebijakan yang dilakukan oleh perusahaan dalam hal ini dapat memakmurkan para pemegang saham biasa atau tidak. Para manajer keuangan sering kali tidak mempertimbangkan kemakmuran pemegang saham biasa melainkan mementingkan kekayaan pribadi atau perusahaannya. Hal ini tentu saja tidak sesuai dengan tujuan perusahaan sebagaimana menjaga hubungan kepada stakeholder salah satunya yaitu pemegang saham biasa sehingga tidak akan mempengaruhi investor sebagai dasar pengambilan keputusan investasi yang berdampak pada perubahan harga saham.

Implikasi hasil penelitian. Pertama. Seluruh hipotesa yang diteliti dalam penelitian ini tidak seluruhnya dapat dijadikan pengambilan acuan yang mutlak bagi para pihak yang berkepentingan, khususnya investor. Kedua. Sampel yang digunakan adalah industri manufaktur satu sub sektor saja yaitu perusahaan semen yang berjumlah tiga, maka tidak mewakili objek penelitian seluruh perusahaan terbuka yang terdaftar di Bursa Efek Indonesia. Dalam pemilihan sampel harus lebih banyak agar menunjukkan hasil penelitian ini yang digeneralisasi pada seluruh industri sehingga dapat dijadikan dasar pengambilan keputusan investasi saham di Pasar modal. Ketiga. Perbedaan kebijakan keuangan yang digunakan setiap Perusahaan sangat berbeda satu sama lain. Adapun dalam penelitian ini yang diteliti hanya terdapat rasio Total Asset Turn Over, Return On Asset dan Return On Equity. Peneliti tidak melakukan upaya agar semua analisa rasio keuangan dapat digunakan untuk penelitian.

\section{PENUTUP}

Simpulan. Model yang dihasilkan dalam penelitian ini adalah model common effect yang merupakan pendekatan data panel paling sederhana dalam pengolahannya dapat disebut juga model Pooled Least Square (PLS) karena hanya mengkombinasikan data time series dan cross section yang berarti model ini dalam dimensi waktu maupun perilaku individu tidak berbeda berbagai kurun waktu dan dapat diasumsikan bahwa perilaku data antar perusahaan sama dalam berbagai rentang waktu. 
Dalam pengujian hipotesis telah diperoleh sebagai berikut: (1) Koefisien regresi Total Asset Turn Over terdapat hubungan positif terhadap Accumulation Distribution Line yang menunjukan bahwa kenaikan harga diikuti dengan kenaikan volume yang merupakan indikasi trend bullish, (2) Koefisien regresi Return On Asset dan Return On Equity terdapat hubungan negatif terhadap Accumulation Distribution Line yang menunjukan bahwa kenaikan harga tidak diikuti dengan kenaikan volume yang merupakan indikasi trend bearish, (3) Total Asset Turn Over, Return On Asset dan Return On Equity berpengaruh signifikan terhadap Accumulation Distribution Line, (4) Total Asset Turn Over dan Return On Asset secara individu berpengaruh positif signifikan, (5) Return On Equity secara individu tidak berpengaruh signifikan terhadap Accumulation Distribution Line.

Saran untuk penelitian selanjutnya. Penelitian ini bermanfaat untuk mengetahui trend harga dan mengindentifikasi pergerakan volume perdagangan saham yang dapat mendorong para investor sebagai dasar pengambilan keputusan investasi sehingga para pemegang saham dapat menilai kinerja keuangan yang berdampak pada perubahan harga dan volume. Oleh karena itu, penelitian selanjutnya diarahkan untuk memperluas jumlah sampel yang digunakan tanpa harus terbatas dengan status Perusahaan terbuka yang terdaftar di Bursa Efek Indonesia sehingga dapat menghasilkan hasil penelitian yang lebih komprenshif.

Sehubungan data rasio keuangan yang diteliti jumlahnya sedikit, maka dalam penelitian selanjutnya diarahkan untuk menggunakan seluruh rasio keuangan agar dapat memberikan rekomendasi dan saran yang kuat bagi para pihak yang berkepentingan, khususnya investor. Peneliti berharap penelitian selanjutnya dapat memberikan temuan baru yang memperkuat dan menjadi acuan sehingga dapat menyatakan bahwa rasio keuangan yang diperoleh dari Indonesian Capital Market Directory (ICMD) dan laporan keuangan audit tahunan mencerminkan kondisi perkembangan Perusahaan pada profitabilitas untuk melangsungkan hidupnya harus dalam keadaan menguntungkan/ profitable. Tanpa adanya keuntungan akan sangat sulit bagi Perusahaan untuk menarik modal dari luar. Para kreditur, pemilik Perusahaan dan terutama pihak manajemen akan berusaha meningkatkan keuntungan ini karena betapa pentingnya bagi masa depan Perusahaan. Penelitian selanjutnya semoga dapat memperkaya studi manajemen keuangan, analisa laporan keuangan dan manajemen investasi.

\section{DAFTAR RUJUKAN}

Alwiyah, Liyanto, (2012) Analisa Teknikal untuk Mendapatkan Profi dalam Forex Trading Online. Buletin Studi Ekonomi. Vol. 17, (2) hal 221 - 228.

Berto Usman, Ridwan Nurazi, Iskandar Zulkarnain, (2012) Analisis Akurasi Bearish Versus Bullish dengan menggunakan Candlestick Analysis: Studi Empiris terhadap Indeks Saham Lq45 (1999-2012). Jurnal Management Insight. Vol. 7, (2) hal 154 171.

Bugrahan Ayanoglu, (2013) Mathematical Back Ground Of Technical Indicator And Their Applications. Faculty Of Science And Letter Graduation Project. Thesis Istanbul Technical University. 
Danika Reka Artha, Noer Azam Achsani, Hendro Sasongko, (2013) Analisis Fundamental, Teknikal dan Makroekonomi Harga Saham Sektor Pertanian. Jurnal Manajemen Keuangan. ISSN 1411 - 1438, Vol. 16, (2) hal 175 - 184.

Dergibson Siagian dan Sugiarto, (2006) Metode Statistika. Cetakan ketiga. Gramedia Pustaka Utama. Jakarta.

Farkhan, Ika, (2012). Pengaruh Rasio Keuangan terhadap Return Saham Perusahaan Manufaktur di Bursa Efek Indonesia (Studi kasus Pada Perusahaan Manufaktur Sektor Food And Beverage). Jurnal Manajemen Keuangan. Vol. 9, (1) hal 1 - 18.

Fillya Arum Pandansari, (2012) Analisis Faktor Fundamental terhadap Harga Saham. Accounting Analysis Journal. ISSN 2252 - 6765, Vol. 1, (1) hal 28 - 34.

Gujarati, Damondar N, (2003) Basic Econometrics, Fourth edition, Macgraw- Hill Highher Education, International Edition, United States Military Academy, West Point, New York.

Hana Mariana, Wahidahwati, (2008) Pengaruh Faktor-Faktor Fundamental dan Teknikal terhadap Harga Saham. Jurnal Akuntansi, Manajemen Bisnis dan Sektor Publik. ISSN 1829 - 9857, Vol. 5, (1) hal 105 - 118.

Hasrul Siregar dan Fatimah, (2013) Analisis Pengaruh Faktor Fundamental terhadap Return Saham Perbankan. Jurnal Manajemen Bisnis STIE IBBI. ISSN 1858 - 3199, Vol. 19, (1) hal 3-10.

Meek, G.K., Roberts, C.B., Gray, S.J, (1995) Factors Influencing voluntary annual report disclosures by US, UK, continental European MNC. Journal of International Business. Vol. 26, (3) hal 555 - 572.

Oberlechner, Thomas, (2001) Fundamental Analysis in the European Foreign Exchange Market. Journal International of Finance and Economics. Vol. 6, Issue 1, hal 81 93.

Primsa Bangun dan Stevanus Adree Cipto Setiawan (2012) Analisis Pengaruh Earning, Cash Flow, Nilai Buku dan Nilai Pasar terhadap Pergerakan Stock Return Pada Saham Lq 45 di Bursa Efek Indonesia. Jurnal Akuntansi. Vol. 8, (1) hal 51 - 66.

Roza Thohiri dan Imelda Sirahar, (2013) Pengaruh Informasi Arus Kas dan Laba Bersih terhadap Volume Perdagangan Saham Pada Perusahaan Manufaktur yang terdaftar di Bursa Efek Indonesia. Jurnal BINA Akuntansi - IBBI. ISSN 1858 - 3202, Vol. 19, (2) hal $27-46$.

Rowland Bismark Fernando Pasaribu, (2008) Pengaruh Variabel Fundamental terhadap Harga Saham Perusahaan Go Public di Bursa Efek Indonesia. Jurnal Ekonomi dan Bisnis. ISSN 1978 - 3116, Vol. 2, (2) hal 101 - 113.

Roscoe dikutip dalam Uma Sekaran, (2006) Metodologi Penelitian Bisnis, Buku kedua, Salemba Empat, Jakarta.

Szabo, Andy CFA, (2004) Timing the Stock Market. Charles Down And His Theory. Greanwich Financial Managemen Inc.

Teguh Jiwandono, (2014) Analisis Faktor Fundamental Terhadap Harga Saham Sektor Perbankan yang Go Public di Indeks Kompas 100. Jurnal Ilmu Manajemen I. Vol. 2, (3) hal $783-794$.

Waworuntu, Stephanus Remond, Suryanto, Hendra (2010) The Complementary Nature Of Fundamental And Technical Analysis. Evidence From Indonesia. Jurnal Manajemen Bisnis. Vol. 3, (2) hal 167 - 184. 
Yeye Susilowati, Tri Turyanto, (2011) Reaksi Signal Rasio Profitabilitas dan Rasio Solvabilitas terhadap Return Saham Perusahaan. Jurnal Dinamika Keuangan dan Perbankan. ISSN 1979 - 4878, Vol. 3, (1) hal 17 - 37.

Zulkarnain, Iskandar, (2012) Akurasi Grafik Main Chart dalam Prediksi Harga Saham Harian: Kasus The Winnest dan The Losest. Jurnal Ilmiah STIE MDP. Vol. 1, (2) hal $74-83$. 